\title{
Bedouin Rising: How Saudi Female Entrepreneurs are Leading Saudi Arabia into a Knowledge-Based Economy
}

\author{
Mark H. Troemel \\ University of Richmond \\ mark.troemel@richmond.edu \\ Patricia B. Strait \\ University of Richmond \\ pstrait@richmond.edu
}

\section{Doi:10.5901/ajis.2013.v2n9p346}

\section{Abstract}

Over the last decade, the unemployment rate of women has been triple that of men in Saudi Arabia. Cultural obstacles perpetuated by the conservative patriarchy of the Kingdom such as guardianship, gender segregation, and childcare options continue to obstruct the entry of Saudi women into the workforce. In response to these entrenched social practices, an increasing number of women have chosen to develop entrepreneurships as a way to circumnavigate these barriers. This essay examines how entrepreneurship has allowed Saudi women to transcend social barriers and achieve financial security and greater social freedom without compromising their traditional matriarchal roles. Specifically, Saudi women have employed four tactics to circumnavigate barriers and achieve greater freedom via entrepreneurships. These tactics include obtaining funding from family members, exploiting higher education opportunities, leveraging technology, and utilizing social networking. By employing creative problem solving strategies, Saudi women have entered the labor force and elevated their status beyond traditional roles. These female entrepreneurs have also secured a place for their families in the middle class and achieved work-life balance through flexible scheduling. This essay concludes with recommendations for specific actions that Saudi businesswomen can undertake to maintain their place in the labor market and aid Saudi Arabia in its transition into a knowledge-based economy.

Keywords: entrepreneurship, Saudi women, social barriers, work-life balance

\section{Introduction}

Before oil was discovered in 1938, Saudi women performed farm work, wove wool, produced handcrafts, and tended livestock (Fallatah, 2012). After the oil boom, the number of women who worked outside of the home dropped precipitously as men stepped forward as the principal income earners (ibid.). Although the increased incomes of the Saudi men provided Saudi women with a more comfortable lifestyle, it also marginalized their participation in the labor force. In 2012, the Kingdom's unemployment rate stood at 12.1\% (Central Department of Statistics and Information, 2013a). When segregated by gender, the unemployment rate for women was $35.7 \%$ compared to only $6.1 \%$ for men (ibid.). Notably, $42.5 \%$ of unemployed women were concentrated within the $25-29$ age range (Central Department of Statistics and Information, 2013b).

In response to social practices inhibiting their workforce participation, an increasing number of entrepreneurial women have started small businesses. Currently, Saudi women own almost 20,000 commercial enterprises (Doumato, 2010) or $12 \%$ of all Saudi companies, including $16 \%$ of the large manufacturing firms (AlMunajjed, 2010). Female-owned businesses (registered and unregistered) operate in a wide variety of industries with many of these businesses concentrated in the creative arts such as interior design, photography, and fashion (Alturki and Braswell, 2010). Other fields with a significant presence of Saudi women include retail and wholesale, beauty salons, and professional services such as consulting, marketing, and event planning (ibid.). More than three-quarters of Saudi businesswomen directly own their operations with registered companies employing an average of 19 workers (ibid.). Further, women in the Kingdom control $40 \%$ of the private wealth, including $20 \%$ of all corporate stock, $10 \%$ of real estate, and hold bank accounts with deposits totaling $\$ 11.9$ billion (Abdul Ghafour, 2003). Through establishing small businesses, Saudi women have used the vehicle of entrepreneurship to bypass many of the social constraints that block more traditional paths to 
employment in the public and private sectors. This paper will examine these cultural barriers and how Saudi businesswomen have been able to transcend them.

\section{Literature Review}

Saudi Arabia remains the most conservative patriarchal nation state in the Gulf Cooperative Council (GCC) regional group that includes Bahrain, Kuwait, Oman, and Qatar (Willoughby, 2008). The cultural forces of male guardianship, gender segregation, and a lack of childcare centers continue to impede the independence of Saudi women.

Guardianship as an Employment Barrier: In Saudi Arabia, men as the legal heads of the household generally control all decisions that affect the family (Hoveyda, 2005). In the Islamic tradition, men support their wives and families and women take care of the children and manage domestic duties (Pharaon, 2004). Based on family law originating from the Qur'an, women are considered "legal minors under the eternal guardianship of their male family members" (Hoveyda, 2005, p. 422). Accordingly, every woman has a guardian regardless of her age. Until recently, guardians had to grant permission before women could acquire an identity card or passport, enroll in school, marry, work, obtain a business license, travel or receive medical care (Andersson and Togelius, 2010). In 2004, King Abdullah issued a series of royal decrees that have begun to gradually erode the guardian relationship. As crown prince, he has authorized women to transact business, to receive bank loans, and to obtain commercial licenses without guardian approval (Ahmad, 2011). After ascending the throne in 2005, King Abdullah consolidated this shift towards acknowledging the "equal valuation" of the different contributions made by men and women (Metcalfe, 2008, p. 96). By 2008, women could independently seek employment and were allowed to stay in hotels by themselves (Flynn, 2011). In 2009, the government pledged to abolish guardianship in its entirety, although no legislative action has taken place to completely eliminate this system (Human Rights Watch, 2010). Although the changes described above are noteworthy, women still cannot drive a car alone or use public transportation without the written consent of their closest male relative (Ahmad, 2011). The requirement of a guardian's approval to travel abroad also hinders women from attending conferences and workshops and developing business relationships with international clients (Alturki and Braswell, 2010). Furthermore, women must still have an authorized male representative to manage their businesses unless products and services are provided only to female clientele (AlMunajjed, 2010). Lastly, hospitals require the permission of male guardians before women can be admitted and undergo medical procedures (Andersson and Togelius, 2010).

Gender Segregation as an Employment Barrier: In Saudi Arabia, most work places remain strictly segregated by gender (Human Rights Watch, 2010). Recent laws seeking to affirm the right of all Saudi women to work without discrimination have been viewed as largely symbolic in nature (ibid.). In 2006, the new Saudi Labor Law dropped specific requirements that businesses have separate work areas, entrances, and elevators for men and women (ibid.). However, Article Four of the law requires all work-related provisions to adhere to the rulings of the Islamic Shari'a" (ibid.). Based on Article Four of the Saudi Labor Law, clerics promptly reasserted the requirement for gender-segregated work places. Given the expense of creating separate work sections for men and women, private businesses have largely resisted hiring women. According to the Ministry of Labor in 2009, only $6.9 \%$ of Saudi females worked in the private sector compared to $17.7 \%$ of Saudi males (Shehadi, et al., 2011).

Childcare as an Employment Barrier: Saudi women with children face a pervasive lack of childcare facilities, both independent and business-sponsored. As of 20 years ago, only 40 daycare centers existed in the Kingdom (Bahry, 1982). The fact that childcare centers are unlicensed makes it difficult for researchers to ascertain their exact numbers, sizes and locations. However, various surveys of Saudi women indicate that the lack of childcare options prevents many women from applying for private sector jobs or even starting their own businesses. Family support systems, however, do help women to manage work and family responsibilities (Metcalfe, 2008). Many consulting firms have stressed the need for more extensive social services support programs such as childcare centers (Saddi, et al., 2009). Similarly, a recent panel of business leaders, academics, and directors of non-profit organizations who gathered at the Dubai School of Government recommended the adoption of national-level policies regarding maternity leave, childcare, and transport to sustain the long-term productivity of women (Grey, 2010). Finally, a recent study found that $79.4 \%$ of working women and $70 \%$ of business managers agree that providing childcare facilities would attract more women into private sector employment (Al-Shetaiwi, 2002).

Overcoming Obstacles and Embracing the Entrepreneurial Model: In response to the obstacles of the guardianship system, the unwillingness of the private sector to create separate workspaces, and the lack of accessible childcare, Saudi women have started small businesses to realize their financial and social goals. Husbands and male guardians have largely supported their business endeavors because the small business model allows women to maintain their traditional matriarchal roles while proving additional income to their families. Overtime, Saudi businesswomen have 
developed a pragmatic combination of solutions to transcend these cultural obstacles. These solutions include: creative funding and partnership; (2) advanced education; and (3) the use of technology.

Funding and Partnership: In general, Saudi women utilize personal savings or funding from family and close friends rather than external financing when starting their businesses (Alturki and Braswell, 2010). Eight out of 10 businesswomen fund their companies with personal savings and $14.5 \%$ seek a loan or a contribution from family or friends (ibid.). Only 7.6\% of Saudi businesswomen take out personal bank loans while $8.6 \%$ receive grants or loans from government or philanthropy funds (ibid.). A number of factors may explain why female entrepreneurs fail to apply for bank loans in greater numbers. First, a majority of Saudi businesswomen regard accessing capital to be a challenging process and prefer to have assistance from male family members (Alturki and Braswell, 2010). Second, there is a dearth of female business lawyers and accountants in the Kingdom with whom they can consult about external financing (ibid.). Most female business owners involve male family members such as husbands or uncles in the businesses either as advisors or partners. Male relatives often complete much of the initial paperwork for the business, including license registrations and occasional feasibility studies (Alturki and Braswell, 2010). While using one's personal savings and family members to start companies may be expedient, management consultants contend that obtaining additional capital will prove essential to future business expansion (ibid.).

Advanced Education: Specialized education and international exposure have helped female entrepreneurs to develop the critical financial, technical and communication skills necessary to establish successful small businesses. Saudi female entrepreneurs possess significantly higher levels of education than the national workforce. In terms of postsecondary education, $58 \%$ of Saudi businesswomen are university graduates compared to only $21.3 \%$ of the national workforce (Alturki and Braswell, 2010). Moreover, 10.9\% of registered businesswomen also hold a postgraduate degree and $32.3 \%$ have studied abroad (ibid.). Saudi businesswomen also tend to pursue degrees that provide them with specific skills that can be applied to entrepreneurship. Based on Ministry of Education statistics from 2006, 28.2\% of Saudi businesswomen concentrated in business disciplines compared to only $2.9 \%$ of men.

Leveraging Technology: Between 2001 and 2011, the number of Internet users in the Kingdom grew from about one million users in 2001 to over 12.5 million users in 2011 (Al-Mowalad and Putit, 2012). With a national population of approximately 22 million, almost $60 \%$ of Saudi citizens are currently plugged into Internet (Gamble, 2011). Based on this increase in Internet access, revenue from online transactions doubled from \$278 million in 2002 to \$556 million in 2005 (Al-Mowalad and Putit, 2012). The Ministry of Economy and Planning in Saudi Arabia has recognized the crucial role of e-commerce in transforming the national economy from oil-dependent to knowledge-based as noted in its long-term development plan of 2005. In a recent study, IT literacy in the Arab world was estimated to be $29.7 \%$, which is higher than the global average of $19 \%$. The Arab League Educational, Cultural and Scientific Organization (ALECSO) argued that GCC governments should fund digital initiatives to further increase IT literacy among women. By promoting IT skills, ALESCO contends that further technological advancement would empower women to "establish home-based businesses" to meet growing service sector demands (Scott-Jackson, et al. 2010, p. 7).

\section{Analysis and Discussion}

Saudi women utilize their own resources and partner with family members to overcome social and legal constraints through entrepreneurship. When consultants focus on how to expand their companies into international ventures, they embrace the Western assumption that Saudi businesswomen like many Western women place equal value on both business and family. Given the typically large number of children in Saudi families and the limited hours available to devote to running their companies, Saudi female entrepreneurs may only be willing to grow their companies to a manageable size that does not compromise their matriarchal obligations. Based on the research references in this essay, female entrepreneurs are beginning to tap into technological advancements such as emailing, automated customer service, new markets, and telecommuting in order to engage with other business owners. By leveraging the Internet as a fully integrated distribution channel, Saudi businesswomen could further increase operational efficiency, track buyer behavior, improve products, refine services, and better manage their supply chains. However, transitioning a company website from a passive informational presence to an interactive platform requires time, resources and strategic planning. The percentage of female entrepreneurs who have successfully developed e-market capabilities remains unclear. Networking among Saudi female business associates and women-business associations is a grossly undeveloped resource due to the overreliance on family members for guidance and funding. The effectiveness of Saudi businesswomen can be strengthened through women's business associations such as the Saudi Management Association and the Jeddah Chamber of Commerce. Given that professional associations often build the underlying infrastructure that facilitates informal networking relationships, increasing membership in these third-party organizations 
will be critical for the transfer of tacit knowledge that promotes business learning. Networking can provide advantages throughout all stages of business development especially during expansion phases when network partners can connect with other ambitious business professionals with venture capital firms. Without accessing the power of networks, female entrepreneurs may never receive the critical advice needed from their seasoned predecessors such as how to translate novel concepts into practical plans, apply for external financing, increase customers, locate suppliers, and solve work-life balance issues. The majority of Saudi businesswomen agree that the small business model offers inherent flexibility to generate income for their families and fulfill their matriarchal roles at the same time. In maintaining work-life balance, female entrepreneurs have benefitted from the support of family, flexibility of hours, and the availability of domestic servants. Given that most businesswomen are married with several children, both spousal encouragement and domestic help appear to be essential factors in accomplishing both professional and household responsibilities.

\section{Conclusion}

By utilizing their personal savings and family resources for business funding and formation, Saudi women have entered the labor force and elevated their status beyond traditional roles. As Saudi businesswomen seek to improve operations and diversify product lines, an increase in the number of female lawyers, accountants and consultants in the Kingdom is needed to provide critical guidance regarding external financing options and business formation strategies. Female entrepreneurs could also benefit greatly from further networking to acquire new business skills, access new markets and bolster social capital. Collaborative networking could further facilitate the rapid transfer of tacit knowledge, increase operational efficiencies, augment customer referrals, advance technology, and encourage innovation. By pooling their considerable wealth to form venture capital firms, Saudi women could also obtain additional funding sources to exploit new business opportunities presented in a knowledge-based economy. The government could assist in this effort by sponsoring digital initiatives to encourage the establishment of home-based businesses by offering e-learning programs, subsidizing the acquisition of computerized systems, and providing free Internet access for limited time periods. Many information intensive businesses such as financial services, translation and tourism, conform to the home-based model. Moreover, certain knowledge-based services can be outsourced to women working from home, such as telemarketing, market research and helplines. While a great deal of information about business funding and formation has been gathered, additional research is needed to investigate how female entrepreneurs can continue to capitalize on new opportunities to lead Saudi Arabia toward a knowledge-based economy.

\section{References}

Abdul Ghafour, P. K. (2003, June 4). Women to take up business issues with Shoura Council. Arab News. Retrieved on 11/19/12 from http://www.arabnews.com/node/232466

Ahmad, S. Z. (2011). Evidence of the characteristics of women entrepreneurs in the Kingdom of Saudi Arabia. International Journal of Gender and Entrepreneurship, 3(2), 123-143.

Al-Mowalad, A. \&Putit, L. (2012). Factors that influence Saudi consumers behaviors to make online purchase. International Conference on Management, Behavioral Sciences and Economic Issues, 2012. Penang, Malaysia.

Al-Shetaiwi, A. (2002). Factors affecting the underutilization of qualified Saudi women in the Saudi private sector (Doctoral dissertation, Loughborough University).

AlMunajjed, M. (2010).Women's employment in Saudi Arabia: A major challenge. Booz \& Company. Retrieved on 11/19/12 from http://www.ideationcenter.com/media/file/Womens_Employment_in_Saudi_Arabia_FINAL.pdf

Alturki, N. \& Braswell, R. (2010). Businesswomen in Saudi Arabia: Characteristics, chällenges and aspirations in a regional context. Monitor Group. Retrieved on 11/19/12 from http://www.monitor.com/Portals/O/MonitorContent/imported/MonitorUnitedStates/ Articles/PDFs/Monitor Businesswomen in Saudi Arabia Dec 6 2010.pdf

Andersson, E. \&Togelius, L. (2010). Women oppressed in the name of culture and religion: Saudi Arabia and the convention on the elimination of all forms of discrimination against women (Unpublished master's thesis, Malmo University).

Bahry, L. (1982). The new Saudi woman: Modernizing in an Islamic Framework. Middle East Journal, 36(4), 502-515.

Central Department of Statistics and Information (2013a). Unemployment rates

(15 years and above) by sex, 1433(2)-2012R2. Central Department of Statistics and Information, Kingdom of Saudi Arabia, Riyadh, Saudi Arabia. Retrieved on 04/13/13 from http://www.cdsi.gov.sa/english/index.php?option=com_docman\&ltemid=162

Central Department of Statistics and Information (2013b). Saudi labor force (15 years and over), by age group and sex, 1433H-2012D. Central Department of Statistics and Information, Kingdom of Saudi Arabia, Riyadh, Saudi Arabia. Retrieved on 04/13/13 from http://www.cdsi.gov.sa/english/index.php?option=com_docman\&ltemid=162

Doumato, E. A. (2010). Saudi Arabia. In. S. Kelly \& J. Breslin (Eds.), Women's rights in the Middle East and North Africa: progress amid resistance (pp. 1-33). New York, NY: Freedom House. 
Fallatah, H. (2012). Women entrepreneurs in Saudi Arabia: Investigating strategies used by successful Saudi women entrepreneurs (Master's thesis, Lincoln University).

Flynn, P. (2011). The Saudi Arabian labor force: A comprehensive statistical portrait. The Middle Eastern Journal, 65(4), 575-586.

Gamble, P. (2011). The Saudi economy in 2012. Jadwa Investment. Retrieved on 09/22/12 from http://www.jadwa.com/en /researchsection/research/economic-research

Grey, S. (2010). Growing aspirations: Supporting women's entrepreneurship in Saudi Arabia and the Gulf. Proceedings report of the panel discussion. Dubai School of Government, Dubai, United Arab Emirates.

Hoveyda, F. (2005).Arab women and the future of the Middle East. American Foreign Policy Interests, 27(5), 419-438.

Human Rights Watch (2010). Looser rein, uncertain gain: A human rights assessment of five years of King Abdullah's reforms in Saudi Arabia. Human Rights Watch. Washington, DC. Retrieved on 11/19/12 from http://dspace.cigilibrary.org/jspui/bitstream /123456789/29761/1/Looser\%20Rein,\%20Uncertain\%20Gain.pdf?1

Metcalfe, B. D. (2008). Women, management and globalization in the Middle East. Journal of Business Ethics, 83(1), 85-100. Pharaon, N. A. (2004). Saudi women and the Muslim state in the twenty-first century. Sex Roles, 51(5/6), 349-366.

Saddi, J., Sabbagh, K. \&Shediac, R. (2009). The challenges of balance. strategy+business, 55, Booz \& Company. Retrieved on 11/19/12 from http://www.strategy-business.com/article/09202?gko=e913b

Scott-Jackson, W., Kareim, B., Porteous, A. \&Harb, A. (2010). Maximising women's participation in the GCC workforce. Oxford Strategic Consulting, Oxford, UK. Retrieved on 11/25/12 from http://www.osc.ae.org/OSC\%20GCC\%20women\%20participation\%20in \%20workforce\%20draft\%20report.pdf.

Shehadi, R., Hoteit, L., Tarazi, K. \& Lamaa, A. (2011). Educated, ambitious, essential: Women will drive the GCC's future. Booz \& Company. Retrieved on 11/19/12 from http://www.booz.com/media/uploads/BoozCo-Educated-Ambitious-Essential.pdf

Willoughby, J. (2008). Segmented feminization and the decline of neopatriarchy in the GCC countries of the Persian Gulf. Comparative Studies of South Asia, Africa and the Middle East, 28(1), 184-199. 